\title{
栃木県茂木町の「美土里館」における「美土里たい肥」での落葉買取の実態 \\ Actual Acquisition of Fallen-leaves in the "Midori Center" of Motegi-Town, Tochigi Prefecuture
}

\author{
田中 美香※
}

\author{
Mika TANAKA
}

\begin{abstract}
In recent years, the farmer is aging in the intermediate and mountainous area of Japan. Therefore, compost manufacture is difficult for the farmer. On the other hand, dependence of a chemical fertilizer and agricultural chemicals is increasing. The government is promoting compost manufacture and use. The fallen-leaves of Satoyama are required for quality compost manufacture. This research aims at clarifying the actual condition and the subject of fallen-leaves collection by a town office in an intermediate and mountainous area. Examination methods were documentary search, an interview, and participant observation. As a result, the town office is managing the compost factory of organic substances recycling. And the town office is managing the system which purchases fallen-leaves. Recently, the fallen leaves which the town office purchases decreased. The cause is reduction of the collection number and a collection zone. The systems by which a house collects fallen-leaves are decreasing in number. However, organized for collection of fallen leaves has durability. In order to increase those who collect fallen leaves, the increase in the number of zone which collects fallen-leaves is effective.
\end{abstract}

Keywords: conservation of Satoyama, recycling of organic substances, bearer, regional resource キーワード：里山保全, 有機物リサイクル, 担い手, 地域資源

\section{1. 背景と目的}

近年，農業の生産において土づくりが危惧される状況となって いる。具体的には，農地でのたい肥等の使用量が著しく低下し， 化学肥料・農薬への過度の依存が顕著となっている。すなわち, 農業の生産環境は悪化している（農林水産省制定 1999 年 10 月 25 日 11 農産第 6789 号農産園芸局長通知）1）。このことを背景 として, 1999 年に施行された「持続性の高い農業生産方式の導入 の促進に関する法律」は，「持続性の高い農業生産方式の導入を促 進するための措置を講ずることにより，環境と調和のとれた農業 生産の確保を図り，もつて農業の健全な発展に寄与することを目 的」(同法第一条) としている。農業での調和のとれた土づくりに おいて, バイオマス 2) を含む地域資源の利活用は必要不可欠とな る。なお, 本研究の地域資源とは, 有形無形の対象であり, 人間 が関与することにより地域資源として維持活用される資源をさ す3)。

バイオマス利活用に関する先行研究は次の二つに大別できる。 一つ, バイオマスの利活用の可能性に関するものである。上原・ 重松 (2001) 4) は, 離島における循環型地域システムのモデルを 再生可能エネルギーシステムの観点より構築し，その可能性を検 討した。原科・武内 (2004）5）は，バイオマス腑存量とバイオマ ス利活用のシステム可能性や評価と主要課題を明らかにしている。 上原ら (2005） 6) は，里地・里山林の実態調査・分析により，対 象地の現状と潜在的な評価・策定・土地利用モデルを提案した。

もう一つの先行研究は，バイオマス利活用の実態とその課題を 明らかにしたものである。藤科・小沢 $(2005)$ 7) は，バイオマス 利活用システムの実態を明らかにし，その維持可能性を環境への 配慮・経済的効率・社会的均衡の 3 基淮より評価した。五十嵐・ 北野 (2006) 8) は, バイオマス利活用の関連者を対象とした実態 調査から，バイオマス利活用システムの持続に必要な課題を明ら かにしている。

しかしながら，バイオマスの利活用において，行政が主導し行 政区の住民が担い手となって持続しているたい肥製造のシステム
を明らかにした研究は，ほとんど見当たらない9）そこで本研究 は，少子高齢化が進行し農家による良質な土作りが困難になりつ つある中山閒地域において, (1)行政主導によるバイオマスを利活 用しているたい肥の製造実態，(2)たい肥製造の発酵促進剤として 行政による落葉買取の実態と担い手の落葉収集の実態を明らかに することを目的とする。

\section{2. 研究の方法}

\section{(1) 研究対象の概要}

1) 茂木町の概要

北関東である栃木県の東南に位置し，茨城県と接する芳賀郡茂 木町（以下，茂木町）は東西 $12 \mathrm{~km} ・$ 南北 $27 \mathrm{~km}$, 面積 $172.71 \mathrm{~km}$ を範囲としている。八溝山地西麓にある茂木町の地積は(1)山林 (60\%, 内広葉樹が約 60\%) (2)農用地（14\%）を占め, 茂木町 は中山間地域である。なお，茂木町の行政区分は 42 地区となっ ている。

2014 年 8 月時点の茂木町における人口は 1 万 3 千 777 人 $(2000$ 年の 1 万 7 千 466 人から $78 \%$ に減少 $)$, 世帯数は 4,691 世帯 $(2000$ 年の 5036 世帯から 93\%に減少）となっている。また，2010 年 度の国勢調査において, 全国の平均年齢が 45.0 歳であったのに対 し, 茂木町の平均年齢は 51.1 歳となった。すなわち, 高齢化が進 展している。

2)「美土里館」設立の経緯

葉たばこの生産・加工は, 江戸時代から 1990 年まで茂木町に おける農家の重要な換金作物であった。また，茂木町茂木地区に て旧・日本専売公社による茂木煙草製造所は，1905 年から 1977 年まで運営されていた。その間, たばこ産業は茂木町の主要産業 であった。

旧・日本専売公社は，茂木町九石地区にて落葉を主原料とした 腐葉土の製造工場も運営していた。原材料である落葉を収集する 担い手は，葉たばこを生産・加工する農家であった。旧・日本専 売公社は, 農家が里山にて収集した落葉を有料にて買い上げして

\footnotetext{
※東京農工大学大学院連合農学研究科
} 
いた。

旧・日本専売公社は，2000 年に腐葉土の製造工場も閉鎖した。 それに伴い，腐葉士の製造工場は旧・日本専売公社から茂木町役 場一譲渡された。それを受けて，茂木町役場は落葉以外の有機物 も原材料とするたい肥の製造を可能にするため，増設工事を開始 し 2003 年に完了した。なお，この増設工事は，1999年施行され た「家畜排せつ物の管理の適正化及ひ利用の促進に関する法律」 にそくして，茂木町での酪農家の家畜排せつ物を処理する目的も 存在した。

たい肥を製造する「茂木町有機物リサイクルセンター美土里館」 （以下，「美土里館」）は，2003 年 4 月より製造を開始し，2014 年現在も茂木町役場の施設として稼動している。なお，茂木町は 「美土里館」での取り組みにより, 2004 年度農村振興局長賞 (バ イオマス利活用優良表彰) を受賞した。

\section{（2）調査方法}

調査期間は 2014 年 2～8 月までであった。調査対象は, (1)「美 土里館」事務担当全員 3 人，(2)「烏生田地区むらら゙くり協議会」 の里山保全活動を担う 5 人, とした。調查方法は, (1)資料調査 ${ }^{10}$ ) 11), (2)聞き取り，(3)参与観察，とした。

調査対象の選定理由は，(1)「美土里館」が茂木町役場によって 運営されていること，(2)2003 年に設立した「美土里館」が，設 立時点から落葉を有償で買い取るシステムを 2014 年現在持続し ていること，(3)「鳥生田地区むらづくり協議会」が 2003〜2014 年現在まで,「美土里館」に落葉を納入している唯一の組織, にあ る。なお，使用した統計ソフトはSPSS17.0であった。

\section{3. 結果と考察}

\section{（1）「美土里たい肥」の概要}

敷地面積 14,070 m²の「美土里館」は，10 棟からなっている。 具体的には, 原料投入棟・ 円形醗酵攪拌棟・二次発酵棟・乾燥棟・ 製品棟 (「美土里たい肥」の梱包) ・保管庫と副資材保管庫 (落葉・ 間伐材を粉砕したおが粉を保管) ・液肥化装置棟・脱臭棟・管理棟 (事務室)，である。また，管理棟正面にはトラックスケールが設 置され，入出庫するすべての車両の重量を計量・記録している。 それにより，「美土里たい肥」原材料と「美土里たい肥」の小売重 量が記録される。

「美土里館」が製造する「美土里たい肥」の有機物は，(1)主原 料 (家畜排せつ物・家庭系生ゴミ・事業系生ゴミ) ${ }^{12}$ ，（2)副資材 （落葉・「美土里たい肥」・間伐材・粐款 12 )・竹粉）である。す心゙ ての主原料と副資材は「美土里館」に搬入され，各工程をへて 105 日後に有機肥料「美土里たい肥」として製造が完了寸る。年間の 処理能力は 4,441 トン, 稼動日数は年間 315 日間である 13$)$ 。「美 土里たい肥」の主成分は，窒素とリンが各 $0.6 \%$ ・カリ $0.7 \%$ ・微 量要素 14) がバランスよく含まれている。また，製造過程におい て水分の蒸発と異物除去工程を経るため,「美土里たい肥」は，さ

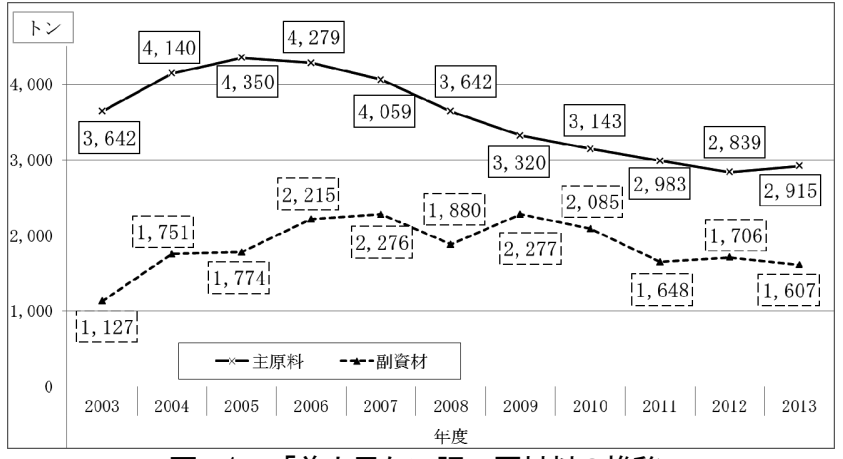

図 - 1 「美土里たい肥」原材料の推移

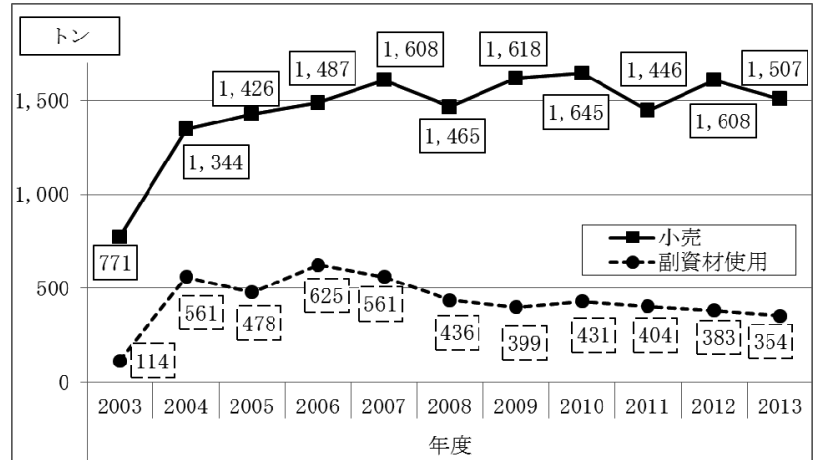

図 - 2 「美土里たい肥」用途別の推移

らさらの良好な状態となり，無臭である。なお，「美土里たい肥」 の発酵促進材は，茂木町内の落葉に付着した土着菌と「美土里た い肥」のみである。

図 - 1 は, 2003〜2013 年度までの「美土里たい肥」原材料の 推移を示した。2003 年 13 戸であった酪農家は, 2014 年時点で 8 戸へと減少した。そのため, 主原料は減少傾向にある。副資材は 多少の変動があるものの，比較的安定的に推移している。

図 - 2 は「美土里たい肥」の用途別（副資材・小売）の推移で ある。「美土里たい肥」の小売 ${ }^{15)}$ において，2006 年度よりほぼ 完売する順調な状況となっている。これは，高品質な「美土里た い肥」の購入者が茂木町内外に存在するためである。なお，「美土 里館」にて製造された「美土里たい肥」は，「美土里館」・「道の駅 もてぎ」にて，1kg（3.6 リットル）100 円にて小売されている。

\section{(2) 落葉収集の実態}

1）「美土里館」による落葉買取システム

「美土里たい肥」の製造は，原材料の 3.5 6.1\%を占める発酵 促進剤である落葉が必要不可欠となる。このため, 「美土里館」は 茂木町内在住者を対象とする回覧板を活用して, 毎年 10～11月 に落葉収集の担い手である落葉収集者を募集し，登録管理してい る。なお，過去の落葉収集者からの応募が今年度に無かった場合，

「美土里館」は過去の落葉収集者一電話し，登録者の増加を推進 する。

落葉収集者登録の条件は, 乾燥した落葉を専用の落葉収集袋 (深 さ $50 \mathrm{~cm}$ ・幅 $60 \mathrm{~cm}$ ・奥行き $80 \mathrm{~cm} ）$ に一袋 $15 \mathrm{~kg}$ 以上收納し，そ の落葉収集袋を 25 袋以上，才なわち一冬に $375 \mathrm{~kg}$ 以上の落葉を

「美土里館」に納入すること，である。「美土里館」が所有する落 葉収集袋は 300 袋（約 $4,500 \mathrm{~kg}$ 分）である。

「美土里館」は，落葉収集者の登録が確定した時点で，約 200 袋（約 $3,000 \mathrm{~kg}$ 分）を落葉収集者一配布する。毎年 $11 \sim 3$ 月の落 葉収集期間は循環的に落葉収集袋を使用し，毎年 1 万 2 千 2 万 2 千袋分の落葉が「美土里館」に納入される。なお，「美土里館」 は町内約 50 ヘクタールの里山から落葉が供給されているとして いる。

平均的な落葉収集者は，60歳以上である。落葉収集者は，いわ ゆる「山の掃除」と称する下草刚りが完了した里山にて, 竹ぼう きを用いた落葉収集を行い，一日に約 $300 \mathrm{~kg}$ 以上の落葉を約 20 袋の落葉收集に梱包する。すなわち，1 日当たり 8,000 円の所 得を得ている。また, 表 - 1 に示したように, 落葉収集者の一冬 当たりの平均的な落葉収集量は $223 \sim 307$ 袋となっており, 約 89,200 122,800 円が落葉収集者の収入となる。

\section{表 - 1 一登録当たりの落葉収集袋の推移（単位 : 袋）}

\begin{tabular}{|c|c|c|c|c|c|c|c|}
\hline 年度 & 2007 & 2008 & 2009 & 2010 & 2011 & 2012 & 2013 \\
\hline $\begin{array}{c}\text { 落葉収集者 } \\
\text { の平均 }\end{array}$ & 264.8 & 255.1 & 241.5 & 237.4 & 223.3 & 307.3 & 237.7 \\
\hline
\end{tabular}


落葉収集の代金は，「美土里館」から落葉収集者の口座一振り込 まれる。具体的には, (1)落葉収集者は当年度最終の落葉収集を「美 土里館」へ納入した後, 茂木町役場所定の書式である請求書に収 した落葉の袋数と振込口座を記入し「美土里館」へ提出，(2)「美 土里館」は落葉収集者が発行した請求書と，当人が納入した落葉 収集袋の数量を精査，(3)「美土里館」は落葉収集者の指定口座に 落葉収集袋一袋当たり 400 円 16) の振り込み，である。

2）落葉収集の減少傾向

図 - 3 は, 2003〜2013 年度の落葉収集量の推移を示した。最 大重量は, 2009 年度の 340 トンであった。しかしながら, 2009 年度以降は減少傾向となり, 2013 年度は 2009 年度の $53 \%$ となっ ている。有機物の発酵促進剤である落葉収集量の減少は，(1)「み どりたい肥」小売分の確保を困難化，(2)「美土里たい肥」の持続

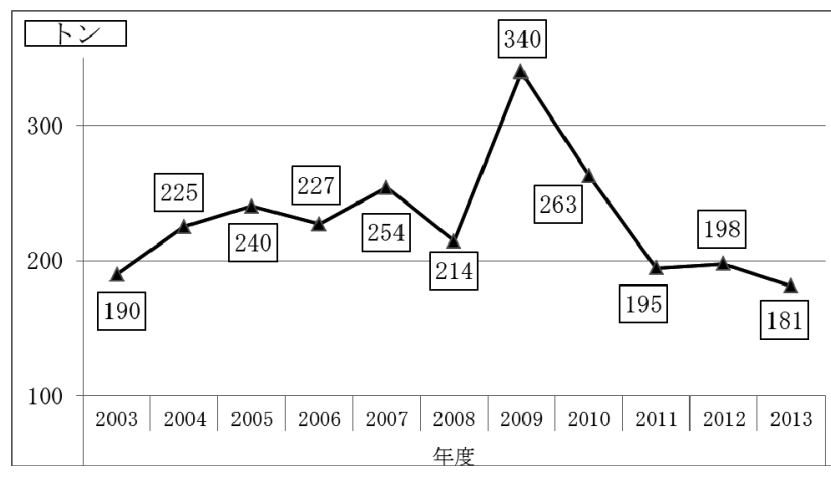

図 - 3 落葉収集量の推移

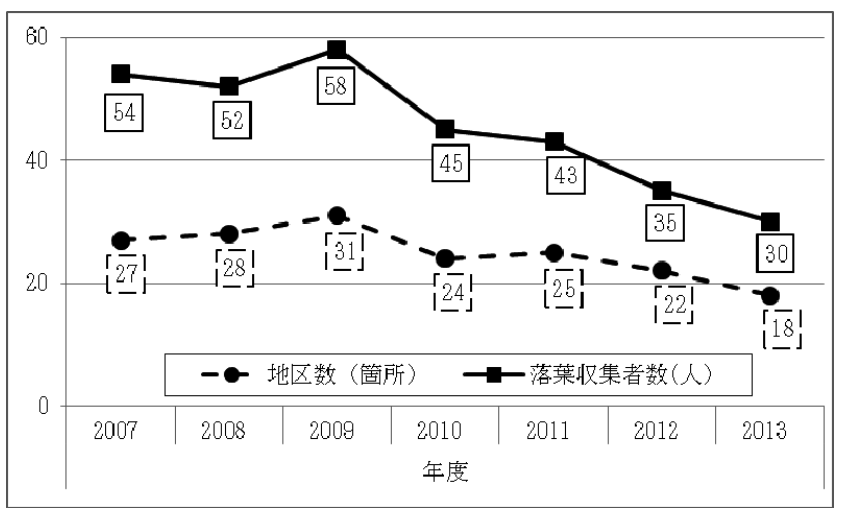

図 - 4 年度別落葉収集地区・落葉収集者の登録推移

表 - 2 1地区当たりの各戸での落葉収集者の推移（単位 : 地区）

\begin{tabular}{|c|c|c|c|c|c|c|c|c|c|}
\hline & \multicolumn{7}{|c|}{ 年度 } & \multirow{2}{*}{$\begin{array}{c}\text { 2007〜 } \\
\text { 2013平均 }\end{array}$} \\
\hline & & 2007 & 2008 & 2009 & 2010 & 2011 & 2012 & 2013 & \\
\hline \multicolumn{2}{|c|}{$\begin{array}{c}\text { 落葉収集地区数 } \\
\text { (䉯所) }\end{array}$} & 27 & 28 & 31 & 24 & 25 & 22 & 18 & 25.0 \\
\hline \multirow{6}{*}{$\begin{array}{c}1 \\
\text { 地 } \\
\text { 区 } \\
\text { 当 } \\
\text { の } \\
\text { 落 } \\
\text { 葉 } \\
\text { 収 } \\
\text { 集 } \\
\text { 者 } \\
\text { 数 }\end{array}$} & 1人 & 12 & 14 & 13 & 11 & 13 & 12 & 10 & 12.1 \\
\hline & 2 人 & 7 & 8 & 14 & 9 & 7 & 7 & 5 & 8. 1 \\
\hline & 3 人 & 5 & 4 & 1 & 1 & 4 & 3 & 2 & 2.9 \\
\hline & 4人 & 2 & 1 & 2 & 2 & 1 & 0 & 1 & 1.3 \\
\hline & 5 人 & 1 & 0 & 0 & 1 & 0 & 0 & 0 & 0.3 \\
\hline & 6人 & 0 & 1 & 1 & 0 & 0 & 0 & 0 & 0.3 \\
\hline \multirow{7}{*}{$\begin{array}{l}\text { 構 } \\
\text { 成 } \\
\text { 比 }\end{array}$} & 1人 & $44 \%$ & $50 \%$ & $42 \%$ & $46 \%$ & $52 \%$ & $55 \%$ & $56 \%$ & $49 \%$ \\
\hline & $2 人$ & $26 \%$ & $29 \%$ & $45 \%$ & $38 \%$ & $28 \%$ & $32 \%$ & $28 \%$ & $32 \%$ \\
\hline & 3 人 & $19 \%$ & $14 \%$ & $3 \%$ & $4 \%$ & $16 \%$ & $14 \%$ & $11 \%$ & $12 \%$ \\
\hline & 4人 & $7 \%$ & $4 \%$ & $6 \%$ & $8 \%$ & $4 \%$ & $0 \%$ & $6 \%$ & $5 \%$ \\
\hline & $5 人$ & $4 \%$ & $0 \%$ & $0 \%$ & $4 \%$ & $0 \%$ & $0 \%$ & $0 \%$ & $1 \%$ \\
\hline & 6人 & $0 \%$ & $4 \%$ & $3 \%$ & $0 \%$ & $0 \%$ & $0 \%$ & $0 \%$ & $1 \%$ \\
\hline & & $100 \%$ & $100 \%$ & $100 \%$ & $100 \%$ & $100 \%$ & $100 \%$ & $100 \%$ & $100 \%$ \\
\hline
\end{tabular}

的な製造が困難となる要因である。

図 - 4 にあるように, 落葉収集者は茂木町の行政区 42 地区中, 18～31 地区 (43〜 74\%) に存在 $\left.{ }^{17}\right)$ する。また, 茂木町全体の落 葉収集者は，30～ 58 人となっている。しかしながら，落葉収集の 地区数・落葉収集者ともに, 2009 年度以降は年々減少傾向にある。 これは，落葉収集者が加齢による体調不良や体力減少を理由に落 葉収集を休止するためである。なお，落葉収集者と落葉収集の地 区数は，y=2.462x-15.020いう関係が見られた $\left(\mathrm{R}^{2}=0.953, \mathrm{p}<\right.$ 0.001 で有意)。すなわち, 落葉収集者の増加は, 落葉を収集する 地区数の増加が必要となる。

表 - 2 において, 1 地区当たりの各戸での落葉収集者は 1〜 6 名 となっている。その内, 落葉収集者が 1 地区 1 名となっている地 区は，毎年度 42～56\%であり，年々増加傾向にある。一方，落葉 収集者が 1 地区 3 6 名となっている地区は, 2007 年度は $30 \%$ を 占めたものの，その後減少傾向となっており，2013 年度は $17 \%$ となっている。すなわち, 各地区内に存在する落葉は, 1 地区に つき $1 \sim 2$ 名の落葉収集者が担い手となり「美土里館」へ納入さ れている。また，1 地区内での落葉収集者の減少傾向は落葉収集 地区の消滅に直結寸るため, 茂木町において落葉収集量減少の要 因となる。なお，後述する「烏生田地区むらづくり協議会」は， 複数地区にて落葉を収集するため, 表 - 2 には含まれない。

3）落葉収集システム

図 - 5 は，茂木町における一般的な落葉収集の形態である。し かしながら, 2009 年度以降, 高齢化の影響により各戸による落葉 収集は, 落葉収集量・落葉収集者共に減少傾向にある (図 - 3・4)。

「美土里館」に落葉を 2003 年度から毎年納入している唯一の 組織である「烏生田地区むらづくり協議会」の落葉収集システム は，図-6 のようになっている。なお，里山保全活動の対象が町 有地である場合は，(2)と(3)の手順は不要となる。

1998 年に 25 人で設立した「烏生田地区むらづくり協議会」は, 都市農村交流である「梅の木オーナ一」制度の設立と運営・烏生 田地区内で生産された梅の加工販売が, 主たる活動となっている。 なお，「烏生田地区むらづくり協議会」はこれらの活動が評価され， 2003 年度農林水産大臣賞（豊かなむららゔくり）を受賞している。

茂木町農林課は図 - 6 の(1)〜(5)に示したようなシステムにて, 「烏生田地区むらづくり協議会」に里山保全活動の依頼を行って いる ${ }^{18)}$ 。それを受けて「烏生田地区むらづくり協議会」は，烏生 田地区内にて各戸で行っていた落葉収集を組織化し, 12 人で里山 保全活動を開始した。

「烏生田地区むらづくり協議会」による里山保全活動を含む落 葉収集は, 冬期の週 4〜 5 日間・毎回 9～16 時となっている。 2014 年現在の 5 人は, (1)年齢が $60 \sim 80$ 代, (2)平均年齢が 73.6 歳, (3)

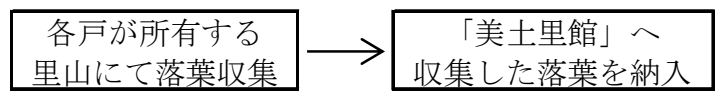

図 - 5 各戸による落葉収集システム

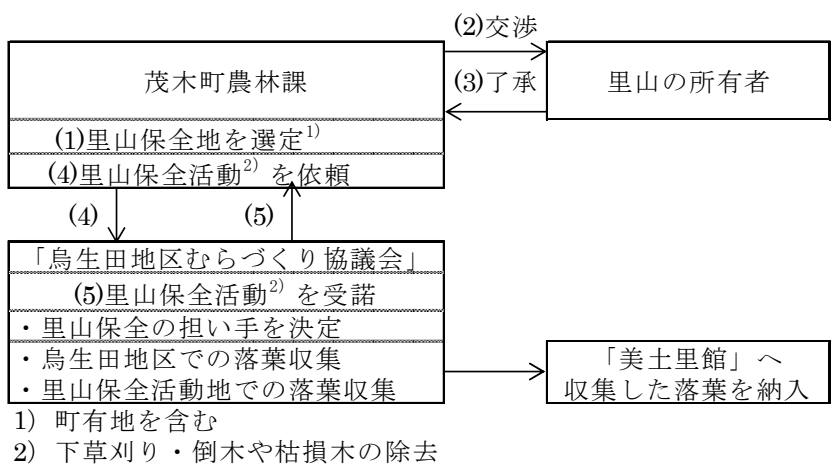

図 - 6 組織化による落葉収集システム 


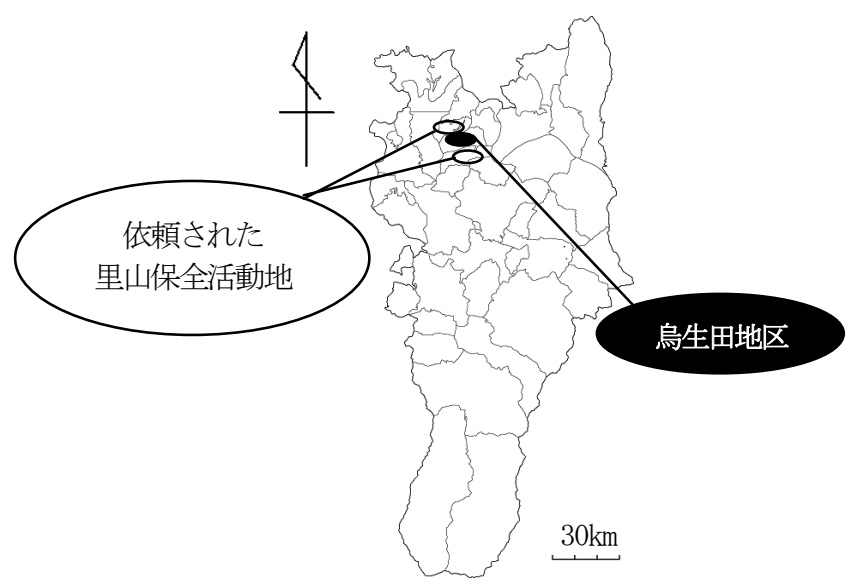

図 - 7 「烏生田地区むらづくり協議会」の里山保全活動地 表 - 3「烏生田地区むらづくり協議会」落葉収集の推移

\begin{tabular}{|c|r|r|r|r|r|r|r|r|}
\hline 年度 & 2007 & 2008 & 2009 & 2010 & 2011 & 2012 & 2013 & 平均 \\
\hline $\begin{array}{c}\text { 里山保全活動 } \\
\text { の担い手 (人) }\end{array}$ & 12 & 12 & 11 & 11 & 5 & 5 & 5 & 8.7 \\
\hline $\begin{array}{c}\text { 落葉の } \\
\text { 袋数 (袋) }\end{array}$ & 503 & 452 & 452 & 801 & 1,580 & 1,534 & 151 & 782 \\
\hline 一人当(袋) & 41.9 & 37.7 & 41.1 & 72.8 & 316.0 & 306.8 & 30.2 & 120.9 \\
\hline
\end{tabular}

落葉収集経験は 4 年目と 6 年目が各 1 人・ 11 年目が 3 人，であ る。また, 里山保全活動の手順は, (1)下草刈り，(2)枯損木の除去, (3)(1)と(2)により荒廃が改善した里山での落葉収集，となってい る。

図 - 7 は, 茂木町 42 行政区と「烏生田地区むらづくり協議会」 の落葉収集の範囲を示した。「烏生田地区むらづくり協議会」は茂 木町農林課から里山保全活動を受諾することにより，烏生田地区 以外での落葉収集が可能となっている。

表 - 3 に示したように, 里山保全活動の担い手は 2009 年度よ り減少している。これは, (1)茂木町農林課からの依頼面積の減少 に応じた人数，(2)高齢化や体調不良により落葉収集を休止したた め, である。2010 年度までは落葉収集者は男性 7 人女性 4 5 人 であった。2011年度以降は, 男性 5 人が里山保全活動の担い手と なっている。なお，年度による落葉袋数の増減は，荒廃した里山 再生に要する期間である。具体的には，下草刈りを $2 \sim 4$ 年間持 続すると, 里山は再生し, 落葉収集が可能となる。その後, 「烏生 田地区むらづくり協議会」の里山保全活動は新たな里山にて実施 される。

\section{4. まとめ}

本研究は，少子高齢化が進行している中山間地域での地域資源 である有機物リサイクルの利活用において，行政が主導し行政区 の住民が担い手となって持続しているたい肥製造，特に落葉買 取・収集システムを明らかにした。

旧・日本専売公社の腐葉士製造工場が所在地行政へ譲渡された ことにともない，行政は町内の多様な地域資源を活用するたい肥 製造工場一と増設した。良質な地域資源から製造するたい肥は高 品質となり，製造分は完売する小売状況が持続している。そのた め，たい肥製造工場は製造設備を最大限に稼動させて，小売への たい肥供給を支えている。

高品質なたい肥製造の発酵促進剤として，地域資源である里山 の落葉は必要不可欠となる。そのため，たい肥製造工場は行政区 内にて落葉収集者を募集登録した後，管理している。落葉収集者 の登録条件は, 一冬に乾燥した落葉 $375 \mathrm{~kg}$ 以上をたい肥製造工場 に納入することである。たい肥製造工場は，落葉収集者が収集し た落葉を買い上げ，落葉収集者の指定口座へ 1 年に一度落葉収集
代金を振り込んでいる。すなわち，地域資源を有償化することに より, 高品質なたい肥の製造は可能となり，里山も保存される。

落葉収集地区と落葉収集者は，年々減少傾向にある。これは， 落葉収集者が加齢による体調不良や体力減少を理由に落葉収集を 休止するためである。この対策として現在主流となっている各戸 が保有する里山での落葉収集システムから, 既に稼動している各 戸が保有する里山以外での落葉収集システムへの移行が急がれる。

今後の課題は，たい肥の購入者が生産する農作物の実態調査と その農作物生産の持続システムを明らかにすることにある。

謝辞: 茂木町環境課の山形様・小林様・森島様, 烏生田地区むらづ くり協議会の皆様に深謝いたします。

\section{補注及び引用文献}

1) 農林水産省: 農林水産省制定 1999 年 10 月 25 日 11 農産第 6789 号農産園芸局長通知

2）本研究のバイオマスとは, 農林水産省の「家畜排せつ物や生ゴミ, 木くずなどの動 植物から生まれた再生可能な有機性資源」をさす。農林水産省 http://www. maff. go. $\mathrm{jp} / \mathrm{j} / \mathrm{biomass} /(2014$ 年 9 月 10 日閲覧)

3) 田中美香 (2014) : 地域資源と地域産業資源の特徴と関係性, 地域活性研究 5 (-), 13-21

4）上原三知・重松敏則 (2001) : 地域資源の保全と有機的活用による循環型地域システ ムの確立に関する基礎的研究 : ランドスケープ研究64(5), 831-834

5）原科幸爾・武内和彦 (2004) : 長野県佐久市を事例とした地域循環型の生物資源利用 システムに関する研究: ランドスケープ研究67(5), 741-744

6) 上原三知・重松敏則・朝野景 (2005) : 都市近郊里地・里山林の保全・活用に上る潜 在的生産力とその循噮型地域モデル : ランドスケーフ研究 68(5), 545-550

7) 藤科智海・小沢瓦 (2005) : 立川町地域資源循噮システムの維持可能性 : 農村計画学 会誌 24 (論文特集号)，43-48

8) 五十嵐春子・北田紀久雄 (2006) : バイオマス利活用における関倸住民の評価- 栃木 県芳賀郡茂木町のアンケート調查を中心に - : 農村計画学会誌 25 (論文特集 号) , 377-382

9）農林水産省が 2004 年度に実施した「たい肥等特殊肥料の生産・出荷状況調查報告書」 は, 4,069 生産業者の回答となっている。その内, 行政である都道府県・市町村の 生産業者数は $71(1.7 \%)$ となった。生産・販売上の課題として, すべての生産業者は 「販売が伸びず採算が取れないを挙げたものの, 都道府県・市町村は $19.7 \%$ と最 も低以回答となった。すなわち, 都道府県・市町村での採算の優位性が示唆された。

10）茂木町農林課（編）(2006）: 美しい土の里から : 栃木県茂木町, 62pp

11）茂木町企画課（編（2014）：おいしい里から : 杤木県茂木町, 76p

12) 2014 年時点, (1)家庭系生ゴミは個人宅 1,449 戸の分別ゴミ，(2)事業系生ゴミは 12 籄所，(3)料款は約 100 戸の農家，から収集されている。

13）2014年8月の聞き取りにおいて，「美土里館」は，約100\%の稼動率となっている。 すなわち，現時点ではこれ以上の「美十里たい肥」の増産は困難である。

14）微量要素は, 次の通り。カルシウム, マグネシウム, 鉄, マンガン, 西鈆, ホウソ, 銅

15）毎年 3 月下旬から 4 月上旬・ 11 月の [美土里館」は，トラックにて「美土里館 に来館した購入者に梱包無しで [美土里たい肥」を小売する。なおう, その購入は(1) 現金決済，(2)購入者の住所の告知，が必須となっている。「美土里館」での「美土 里たい肥」の小売価格は次の通り，(1)梱包済（1kg100 円・10kg500 円），(2) 1袋 $500 \mathrm{~kg}$ フレキシブルコンテナバッグ梱包 (茂木町住民 3, 000 円, 町外 4, 000 円)，(3) 梱包無し $1 \mathrm{t}$ (茂木町住民 5, 000 円，町外 7,000 円)。

16）「美十里館」が落葉収集袋を回収した場合は一袋 400 円。落葉収集者が「美十里館」 一搬入した場合は一袋 430 円。

17） $2008 〜 2012$ 年度に東京都・宇都宮市・益子町の学校やNP0 が社会活動の一環とし て落葉を収集し，「美十里館」に納入した。なお，その収集量は毎年度の $0.1 \%$ 1. $2 \%$

18「鳥生田地区むらづくり協議会」への里山保全活動の委託料は 5 万円/ha。2013 年 度は「森林・山村多面的機能発揮刘策交付金」により 16 万円/ha。委託面積は2 2007 ～2010 年度 15ha, 2011 2012 年度 10ha, 2013 年度 20ha。「烏生田地区むらづくり 協議会」は, 里山保全活動の必要経費を精算後, 里山保全活動の担い手人均等割り した金額を支払う。なお，行政予算の都合上，委託が実施されない年度にも「烏生 田地区むらづくり協礒会」の里山保全活動者は[美十里館に落葉を納入している。 